\title{
Contemporary British Politics
}

Visit the companion website for this text at:

http://www.palgrave.com/politics/coxall/ 


\title{
Contemporary British Politics
}

4th edition

\author{
Bill Coxall \\ Lynton Robins \\ and \\ Robert Leach
}


ISBN 978-0-333-73243-4 ISBN 978-1-349-14821-9 (eBook)

DOI 10.1007/978-1-349-14821-9

(C) Bill Coxall and Lynton Robins 1989, 1994, 1998

(c) Bill Coxall, Lynton Robins and Robert Leach 2003

All rights reserved. No reproduction, copy or transmission of this publication may be made without written permission.

No paragraph of this publication may be reproduced, copied or transmitted save with written permission or in accordance with the provisions of the Copyright, Designs and Patents Act 1988, or under the terms of any licence permitting limited copying issued by the Copyright Licensing Agency, 90 Tottenham Court Road, London W1T 4LP.

Any person who does any unauthorised act in relation to this publication may be liable to criminal prosecution and civil claims for damages.

The authors have asserted their rights to be identified as the author of this work in accordance with the Copyright, Designs and Patents Act 1988.

First published 2003 by

PALGRAVE MACMILLAN

Houndmills, Basingstoke, Hampshire RG21 6XS and

175 Fifth Avenue, New York, N.Y. 10010

Companies and representatives throughout the world

PALGRAVE MACMILLAN is the global academic imprint of the Palgrave Macmillan division of St. Martin's Press, LLC and of Palgrave Macmillan Ltd. Macmillan ${ }^{\oplus}$ is a registered trademark in the United States, United Kingdom and other countries. Palgrave is a registered trademark in the European Union and other countries.

ISBN 978-1-4039-0507-9 paperback

This book is printed on paper suitable for recycling and made from fully managed and sustained forest sources.

A catalogue record for this book is available from the British Library.

Library of Congress Cataloging-in-Publication Data

Coxall, W. N.

Contemporary British politics.- 4th ed. / Bill Coxall, Lynton Robins, and Robert Leach. p. $\mathrm{cm}$

Includes bibliographical references and index.

ISBN 978-1-4039-0507-9 (pbk.)

1. Great Britain-Politics and government-1945- I. Robins, L. J. (Lynton J.) II. Leach, Robert, 1941- III. Title.

JN231.C624 2003

320.941-dc21

Editing and origination by Curran Publishing Services, Norwich

$\begin{array}{llllllllll}10 & 9 & 8 & 7 & 6 & 5 & 4 & 3 & 2 & 1\end{array}$

$\begin{array}{llllllllll}12 & 11 & 10 & 09 & 08 & 07 & 06 & 05 & 04 & 03\end{array}$ 
This book is dedicated to the memory of Bill Coxall 


\section{Contents}

List of figures

List of tables

List of boxes

Preface to the fourth edition

Acknowledgements

List of abbreviations

\section{PART I The Context of British Politics}

\section{Politics, Democracy and Power}

What is politics?

Authority, power and influence

Democracy - power to the people?

Power in Britain

Perspectives on power

British politics?

Multi-level governance

Policies - who gets what, when, how?

\section{Economy, Society and Politics}

Political geography - nation, regions, town and country

Allegiance and identity

Ethnicity

Religion

Gender

Age

Inequalities in income and wealth

Occupation and social class

Changing class structure?

Economic inequality and political power

Economic and social divisions - the time dimension

\section{The Historical Context: British Politics since} 1945

The post-war years: the end of empire and the imperial legacy

The under-performing economy

Building a welfare state

The pendulum years: from crisis to doubt

Economic management: towards 'stagflation' The Thatcher years xii Thatcherite Britain in Europe 43

xiii The welfare state and the free market 44

xv The impact of Thatcherism 45

xix Tony Blair and New Labour 45

xx Between Europe and the Atlantic 47

xxi The new British state - changing political processes

4 Political Ideologies: The Battle of Ideas

3 Ideas and politics

3 The meaning and political significance of

5 ideology

5 Ideological conflict and consensus $\quad 52$

7 Classifying ideologies: left and right $\quad 52$

8 Ideologies and political parties $\quad 52$

11 Liberalism - core interests and values 53

12 Traditional Conservatism 56

13 Thatcherism and the New Right 59

Post-Thatcherism and modern Conservatism 60

16 British socialism or labourism 62 From old to New Labour 65

16 Nationalism 66

18 Racism 68

19 Feminism 69

21 Green thinking 71

23 Globalization and the 'end of ideology' 71

23

PART II Participating in Politics 73

275 Ways of Participating in Politics 75

Political participation $\quad 75$

29 Who participates? 76

Why participate? 78

30 Do individuals need to vote? 79

Public opinion and participation $\quad 79$

Political competence and participation $\quad 80$

32 A changing political culture? $\quad 81$

Political socialisation 83

33 Citizenship entitlements 85

$37 \quad 6$ Election Systems and Electoral Reform $\quad 88$

39 Electoral statistics 88

40 Turnout and outcomes 89

42 Proportionality in general elections 90 
Tactical voting

Electoral systems

Electoral reform in Britain

Referendums

\section{Voting Behaviour}

The decline of the two-party system

The primacy approach: the social basis of voting behaviour

Social class and voting behaviour

Gender and voting

Age and voting

Ethnicity and voting

The recency approach

The image of the party leader

Party images

Can issue preferences explain voting behaviour?

An econometric explanation of voting preference

The 2001 election: a campaign that changed nothing?

Measuring public opinion

\section{Political Parties}

Why parties?

Party systems

Types of party - cadre and mass parties

Ideological and pragmatic parties

Parties and interests

Party cohesion - factions and tendencies

The organisation of parties - power and decision making

The leadership

Parliamentary parties

Party conferences and the national organisation of the parties

The party membership and constituency parties

Power within the parties - the modern party and its membership

The finance of political parties

The future of the British party system

\section{Pressure Groups}

What are pressure groups?

Pressure groups and the political system: history and trends

New social movements
90 Pressure group targets

144

91 Pressure group influence

148

94 Pressure groups and democracy

151

10 The Mass Media and Politics

156

99 The mass media and society

156

99

The 'media as part of democracy' viewpoint

157

The 'media as a tool of the ruling class'

101

viewpoint

159

102

103

104

105

105

107

108

108

Television politics

The 'tabloidisation' of the mass media

162

163

164

165

166

169

\section{PART III British Government: Westminster and Whitehall}

\section{1}

109

11 The Evolving British Constitution

173

What is a constitution?

173

110

The classification of constitutions

174

113

The evolution of the British Constitution

175

The main characteristics of the British
115

115

115

118

118

119

120

121

122

126

Constitution

Representative democracy

The rule of law

Ideological perceptions of the British

Constitution

The movement for constitutional reform

Labour and the constitution: a government of radical reform?

177

180

180

181

183

184

187

187

189

194

195

197

198

200

A 'Blair presidency'?

133 Constraints on prime ministerial

134 government

200

Prime ministerial power: an irrelevant

136 debate?

203

203

Criticism of the British core executive
138

141

\section{Ministers, Departments and the} Civil Service 
The organisation of British central government

The internal organisation of central government departments - politicians and civil servants

The civil service - size and distribution

The British civil service - three major features

Recruitment of the higher civil service issues of expertise and bias

From old public administration to new public management?

The Conservative reforms: a revolution in government?

The Blair government and the civil service

Standards in public life

Ministerial responsibility revisited

Where does power lie? Decision making within departments

The resurgence of the traditional model: do ministers decide after all?

\section{Parliament and the Legislative Process}

The functions of the House of Commons

Representation

Legislation

Scrutiny and influence of the executive

Forum for national debate

Recruitment of a government

Executive dominance of Parliament

Reform of the House of Commons

The upper chamber

Powers and functions of the upper chamber

Composition of the upper chamber

Reform of the upper chamber

The Westminster Parliament and other parliaments

\section{The Law, Politics and the Judicial Process}

The rule of law

Law in England, Scotland and Europe

The courts

The judiciary

The police and policing

Human rights and civil liberties

Administrative law: protecting civil liberties and redressing grievances

Judicial review
Administrative tribunals $\quad 261$

206

Statutory inquiries

262

The ombudsman system

The European Convention on Human Rights

208

209

210

210

213

and the Human Rights Act

264

\section{PART IV Multi-Level Governance:} Government and Politics Above and Below Whitehall and Westminster

267

16 Britain and the European Union

213

216

217

218

222

The European ideal, 1945-58

269

269

Britain and Europe, 1945-73

270

The development of the European ideal:

integration and enlargement

Britain and Europe from 1973 to the present

273

The European Union: superstate or

224 inter-governmental organisation?

The institutions and processes of the European Union

276

The impact of the European Union on the British state and government

The impact of EU membership on British politics: parties, pressure groups and voters

The impact of the European Union on UK policies

The future of the European Union and the relationship between the UK and the EU

17 Devolution: The Disunited Kingdom

The British state

A confused national identity?

Northern Ireland and Irish nationalism

290

291

294

The search for peace in Northern Ireland

Scottish nationalism and the pressure for devolution

The Scottish Parliament and government

Devolution in Wales

Asymmetrical devolution

The English question

English regional government

304

305 
Representing communities and securing accountability

The politics of local governance: local interests and parties

Decision making within organisations: local politicians, managers and professionals

Territory and community: the reorganisation of structure

The delivery of services

Reforming the finance of local governance

Central-local and inter-authority relations under 'multi-level governance'

19 The New British State: Towards Multi-Level Governance

Characterising the modern British state

The attack on government

Restructuring the state: quangos and agencies

Privatisation, contracting out and competition

New Labour and partnership with business and the voluntary sector

Steering, not rowing: the enabling state

The regulatory state

Open government and the secret state

The disintegration of the British state or towards multi-level governance?

\section{PART V Policies and Issues}

\section{The Policy Process}

Policy making and decision making

The political agenda

Decision making theory

The policy making process

Policy analysis

'Joined-up' policy making

Modernising policy making

Political leadership

Sources of policy advice

Policy and implementation

\section{Managing the Economy}

The tools of economic management

Management of the economy: the Thatcher and Major years

Economic management under New Labour A prudent or a gambling chancellor?

352

352

355

356
Britain's open economy

22 Delivering Public Services

369

313 The changing context of public service delivery

314 Investment in the public services

371

Delivering healthcare

372

374

375

376

322 Problems with performance

Rich Britain, poor Britain

Explanations for poverty and inequality: family breakdown

Explanations for poverty and inequality: changes in the labour market - the 30/30/40 society

Fresh approaches: community and stakeholding

381

332 New Labour's anti-poverty programme

Conservative rethinking

24 The Politics of Diversity

Black and British

Countering racism and discrimination

Institutional racism

Multi-cultural Britain?

Including women: the impact of the women's movement on policy

Achievements of the women's movement and areas of controversy

The diversity of alternative lifestyles: lesbian and gay rights

\section{Politics and the Environment}

401

The environmental debate

401

The 'tragedy of the commons'

402

Green ideology

402

The political agenda and the political process

The Green Party

Britain and transnational pollution

The European Union and international 


\section{Foreign and Defence Policies}

The differing nature of external policy

The making of British foreign and defence policies

The basis of Britain's foreign policy

The Commonwealth

The special relationship with the USA

Britain in Europe

The EU versus NATO in British foreign and defence policies

From new world order to the war on terror

Britain and Europe's evolving relationship with Russia

An ethical foreign policy for Britain?

The war on terror

British foreign and defence policies in the 21st century
41027 Who Governs? Power and the New British $410 \quad$ Politics

422

Who gets what, when, how?

422

411 Top-down and bottom-up approaches to

412 politics

412 Participating in politics

423

413 The power of the centre

424

414 Government and governance 426

Multi-level governance

427

414 The segmentation of public policy - policy

416 communities

428

Governance and democracy 429

416 Democracy, equality and power 430

416 The future of British politics 431

419

Bibliography

435

419 Index 


\section{List of figures}

2.1 The population of the United Kingdom of Great Britain and Northern Ireland, 2000

2.2 Gross Domestic Product by head by nation and selected English regions, 1999

2.3 National identity in Scotland, 2000

2.4 Non-white ethnic minorities in Britain (total 4,045,000) in the year 2000

2.5 Unemployment levels by ethnic group

2.6 Unemployment levels among 18-24 year olds by ethnic group

2.7 Religious affiliation, Great Britain, 2000

2.8 Changing patterns of housing tenure in Britain

3.1 Britain's changing political culture

4.1 Left-right, conventional scale

4.2 Tensions within Thatcherism and the New Right

4.3 Influences on the ideology of the Labour Party

5.1 A hierarchy of political participation

6.1 Ballot paper for European Parliament East Midlands region

7.1 Class percentages voting Labour and Conservative, 1945-58

7.2 A framework for analysis of voting behaviour

7.3 Class voting in the 2001 general election (change since 1997 at head of each column)

7.4 Party support by age in the 2001 general election

7.5 Electoral churn

7.6 The most important issues to the electorate, 2001

7.7 2001: a campaign with little impact?

8.1 Spending by parties, 2001 general election

9.1 Insider and outsider groups

9.2 New social movements: typical composition

9.3 Pressure group influence on Whitehall and Westminster: the main stages
9.4 Pressure group power structure

152

12.1 Prime Minister's Office, as reorganised following the 2001 election

13.1 Structure of a typical department of state (civil servants italicised)

17 13.2 Ministers in the Department for

18 Education and Skills, 2002

195

208

13.3 Women employed in the civil service by grade, 2001

209

20

21

14.1 Principal stages in the legislative process for government bills

14.2 Party affiliations of members of upper house, 2001

212

235

248

15.1 The system of courts in England and Wales

254

18.1 The structure of elected local

52

61

18.2 The local authority map in England from 1998

18.3 The 32 unitary authorities in Scotland operational from April 1996

18.4 The 22 unitary authorities in Wales operational from April 1996

9520.1 The policy making process

20.2 The educational policy making

100 process

20.3 Shading opinion

10121.1 The 'stop-go' cycle of the political economy

21.2 The British economy: key indicators, 1990-2002 (smoothed trends)

21.3 The 2002 Budget: income, expenditure and borrowing plans

24.1 The social class of ethnic minority and white males (percentage of each ethnic

109 group in each class)

24.2 Female representation in British parliaments and assemblies as a percentage of the total

13824.3 Women's employment and pay, 1952 and 2002

$142 \quad 26.1$ The British foreign policy making process

14826.2 Defence expenditure, 2000 


\section{List of tables}

1.1 Models of the possible distribution of power

2.1 The distribution of marketable wealth (adults aged 20 or over), 1999

3.1 Post-war British prime ministers

4.1 The Whig-Liberal tradition in Britain

4.2 The evolution of conservatism in Britain

5.1 Recent levels of turnout

5.2 Membership of parties and pressure groups (based on figures for 2001 and 2002)

5.3 Falling electoral turnouts

5.4 Political 'generations' and the political culture, 1960s-1990s

6.1 The 1992, 1997 and 2001 general elections

6.2 Elections to the Scottish Parliament, 1999

6.3 Welsh Assembly Elections, 1999

7.1 When the voting decision was made in 1997 (per cent)

7.2 Sex and party choice in general elections, 1987-97 (per cent)

7.3 Black and Asian voting in the 2001 general election (per cent)

7.4 Voting intentions and perceived economic management competence, May-June 2001 (per cent)

7.5 The 2001 general election results for Great Britain

7.6 The 2001 general election: results for Northern Ireland (changes since 1997 shown in brackets)

7.7 The 2001 general election: results for Scotland (changes since 1997 shown in brackets)

8.1 'Crossing the Floor': recent changes of party by sitting MPs

8.2 Labour leadership election 1994 (first and only ballot)

8.3 How the parties choose their leaders

8.4 The new National Executive Committee of the Labour Party
9.1 Groups' ranking of influences on public policy

9.2 Pressure groups and democracy: for and against

10.1 Newspaper ownership and wider media interests

12.1 Cabinets compared 188

5812.2 Prime ministerial power and constraints

76 on prime ministerial power: a brief summary

14.1 Party composition of the House of Commons after the 1997 and 2001 general elections

14.2 Parliamentary stages of legislation 236

8514.3 Main methods of Commons' scrutiny of the executive

8914.4 Benefits and limitations of departmental select committees (DSCs) 240

$96 \quad 15.1$ Senior judges by gender, $1999 \quad 255$

9616.1 Europe: what's in a name?

16.2 Time chart: key dates in development of the EC/EU and in UK involvement 275

16.3 The location, composition and functions of key European Union institutions 279

16.4 MEPs elected to European Parliament

105 by country (after 1995 enlargement) 280

16.5 Votes and seats for UK parties in European Parliament elections,

110 1979-99

16.6 Party representation in the European Parliament, 1999

16.7 Examples of Europe-wide interest groups

11216.8 Turnout levels: elections for the European Parliament (excluding new member states in 1995)

11317.1 Some of the political parties in Northern Ireland

$121 \quad 17.2$ The June 1998 elections to the Northern Ireland Assembly

17.3 Elections for the Scottish Parliament, May 1999

17.4 Welsh National Assembly: election results, May 1999 
17.5 Devolution in Scotland and Wales compared

18.1 Who does what? English county councils and district councils (principal functions)

19.1 From old government to new governance: the shifting focus

19.2 Types and examples of quangos

19.3 Some of the principal privatisations

19.4 From the old Westminster model to the new British governance
19.5 The new multi-level governance, as applied to Britain

20.1 Differing approaches to policy making

32222.1 Contrasting administrative cultures

22.2 Welfare services: the market and the 369

370 328

331

332 state

24.1 Liberal and radical approaches to equal opportunities

27.1 The transport policy community in Britain: some key players 


\section{List of boxes}

1.1 What is politics?

1.2 Politics, conflict and coercion

1.3 Power, authority and influence

1.4 Democracy - some definitions and observations

1.5 Conditions for representative democracy

2.1 Identity politics, an illustration

2.2 Some social or occupational class categories commonly used in Britain

2.3 Self-assigned class?

3.1 1956: twilight of empire

3.2 The welfare state: the main measures

3.3 Retreat from empire

3.4 The Falklands conflict: a metaphor for Thatcherism?

3.5 The nature of political consensus

3.6 Devolution

4.1 What are political ideologies?

4.2 Core liberal values

4.3 Clause Four of the Labour Party Constitution (1918-95)

4.4 From the New Clause Four (adopted 1995)

4.5 Comparative politics: 'separation nationalism'

4.6 Institutional racism: the Macpherson Inquiry's definition, 1999

4.7 Comparative politics: fascism and racism

5.1 The new politics of participation

5.2 Greenpeace: can direct action be justified in a liberal democracy?

5.3 The confused British citizen

6.1 Types of majoritarian system

6.2 Types of proportional representation system

6.3 The Jenkins Report

6.4 Comparative politics - elections in Germany - an AMS comparison

6.5 The merits and disadvantages of initiatives and referendums

8.1 Main functions of political parties

8.2 Comparative politics: party systems in other countries
7

19

27

28

35

38

39

43

47

48

51

54

63

65

67

68

69

82

83

86

92

93

95

96

97

116

117
8.3 The authority of Labour and Conservative leaders compared

123

8.4 How the Conservative Party elected its leader, 1965-98

124

8.5 Recommendations of the Neill

Committee on party funding, 1998

134

9.1 The Countryside Alliance, September 2002

140

9.2 Comparative politics: left and right social movements in the UK and USA 142

9.3 The National Farmers Union (NFU) 152

9.4 The Royal Society for the Prevention of Cruelty to Animals (RSPCA)

153

10.1 Media values: anti-Semitism and pro-Israeli bias in reporting Middle Eastern affairs?

157

10.2 Do the British public's Euro-sceptic attitudes result from press hostility to the EU?

162

10.3 Comparative politics: the 'watchdog' role of the British and American press

163

10.4 The importance of timing in media political influence: the Zinoviev letter 167

10.5 Looking back to 1992 and 1997: did the Sun win it?

168

10.6 The lobby system

168

176

USA and other countries

11.2 The major sources of the British Constitution

177

11.3 Comparative politics: constitutional monarchies and republics

178

11.4 The main demands of Charter 88

11.5 Constitutional reform: the LabourLiberal Democrat proposals, 1997

183

11.6 The Labour government's legislation on constitutional reform

183

184

11.7 The end of Parliamentary sovereignty and the unitary state?

12.1 The role of the prime minister: key

12.2 Prime ministers and Parliament 193

12.3 The 'kitchen cabinet' 194

12.4 The role of the Cabinet 
12.5 Some important Cabinet committees in Blair's government

12.6 The practical implications of collective Cabinet responsibility

12.7 President Blair? Two contrasting perspectives

12.8 Comparative politics: prime ministers and presidents

13.1 Departmental reorganisation under the Blair government

13.2 Features of the British civil service

13.3 Comparative politics - public bureaucracies in the USA and France, compared with Britain

13.4 Features of new public management

13.5 Example of an executive agency: the Driver and Vehicle Licensing Agency (set up 1990)

13.6 The impact of reform on key attributes of the traditional civil service

13.7 The Nolan Report, 1995: the seven principles of public life

13.8 Extracts from Cabinet Practice: A Code of Conduct and Guidance on Procedure for Ministers

13.9 The politics of individual and collective responsibility

13.10 The Scott Report (1996) - a case studyin the refusal to admit responsibility?

13.11 Constraints on the effective power of ministers

14.1 Unrepresentative MPs

14.2 Maintaining party cohesion and discipline in the House of Commons

14.3 MPs and the representation of interests - some areas of concern

14.4 Comparative politics: the UK Parliament and the US Congress

14.5 Limitations on Private Members' bills

14.6 Reasons for government control of the House of Commons

14.7 Old and interim reformed composition of the House of Lords, after House of Lords Act 1999

15.1 Types of law

15.2 Civil rights in the United Kingdom (and some limitations)

15.3 Grounds for judicial review

207

210
15.4 Rights under the European Convention on Human Rights and its Protocols (summarised)

16.1 Enlargement of the European Community/Union, 1952-2003

16.2 The principle of subsidiarity

277

16.3 Arguments for and against Britain joining the single European currency 286

17.1 The British state: core and periphery 290

17.2 The roots of conflict in Northern Ireland: different perspectives

17.3 The Northern Ireland Executive at the time of suspension (October 2002)

17.4 The Scottish Cabinet, June 2002

21317.5 Comparative politics - the future of Scotland: the Quebec scenario or the Slovak scenario?

17.6 The Welsh Cabinet (June 2002)

301

17.7 The regional development agencies

304

18.1 Some of the appointed councils, authorities and trusts operating at local level, 2000

18.2 Some examples of 'joined-up' policy initiatives

18.3 The case for local democratic institutions

18.4 Comparative politics - running US cities - mayors and city managers

18.5 The community power debate

18.6 The government of London: the London Mayor and Greater London Authority

18.7 The poll tax - a policy disaster

19.1 Executive agencies and quangos

19.2 From Railtrack to Network Rail

19.3 Some important regulatory bodies

19.4 Britain's security services

20.1 Reshaping the political agenda: 'back to basics'

23820.2 The Phillips Inquiry: lessons about policy making

20.3 Contrasting the Thatcher and Blair approaches

21.1 Prices and incomes policies in the 1960 s and 1970 s

21.2 The pro-business party loses the support of business

21.3 Labour and the euro

21.4 The radical Labour budget of 2002 
22.1 Britain's largest PFI contracts (2002)

22.2 Nine key performance indicators for acute hospital trusts

22.3 Law and order

23.1 Political controversy over the meaning of poverty

23.2 New Labour's main anti-poverty measures

23.3 A profile of poverty in Britain

23.4 Identifying the poor

23.5 The pensions crisis: key factors

24.1 Blacks and Asians

24.2 Race riots in northern towns in Britain, 2001: the Ouseley Report

24.3 Islamophobia

24.4 The left, right and centre of good race relations

24.5 Women in Parliament

24.6 The New Feminism

25.1 Political concern about the environment: the five-stage cycle

25.2 A Green transport policy?

25.3 The Environment Agency

25.4 The Kyoto Agreement

26.1 Britain's 'special relationship' with the USA

26.2 The Western European Union

26.3 The views of Francis Fukuyama and Samuel Huntington

26.4 NATO membership status
372 26.5 The Ottawa Convention banning antipersonnel landmines

418

37327.1 Parties and pressure groups: power, 376

27.2 People power or business power?

426

380

383

384

384

385

388

393

395

'In Focus' boxes

1.1 Representative democracy in action! 10

4.1 Margaret Thatcher 60

6.1 Replacing the Conservatives? 94

7.1 Leaders under fire $\quad 107$

8.1 Competing for power 122

9.1 The country comes to town $\quad 141$

10.1 The master of spin? 164

12.1 Where are they now? 188

12.2 The Cabinet, October $2002 \quad 190$

39612.3 The Cabinet in session 196

398 13.1 Whitehall 209

399 14.1 Mother of Parliaments? 227

15.1 Cherie Booth 256

40416.1 Europe's new currency 273

$405 \quad 17.1$ Cooperation between devolved

407 governments 306

$408 \quad 18.1$ The Mayor of London 317

19.1 David Shayler 339

41321.1 Blair and Brown 363

41422.1 Holding the purse strings 371

24.1 A war against terror or a war against

$415 \quad$ Islam? 394

41726.1 The special relationship survives? 420 


\section{Preface to the fourth edition}

This edition of Contemporary British Politics has required more or less complete rewriting to take account of the dramatic changes in British politics since publication of the third edition just one year into New Labour's first term in office.

Most importantly the whole British system of government has been radically overhauled, largely as a consequence of New Labour's constitutional reform programme. Thus in this new edition we have had to not only incorporate extensive new material, but also rethink the analysis of British government in the light of developments which challenge long established constitutional principles and raise fundamental questions about the whole future of the British state.

The international context in which British politics takes place has been transformed by the events of 11 September 2001, the Afghanistan war and the crisis over Iraq. The introduction of the euro in most of the other EU member states and the agreement over enlargement have marked a step change in the development of the European Union, and posed new policy dilemmas for the British government. There have been significant changes in the process and content of British politics, with major developments in almost every field of policy.

The chapter structure of this edition has been modified to take account of the implications of devolution and the increasing significance of the EU, with analysis of the more familiar British government in Whitehall and Westminster in Part III complemented by an assessment of new patterns of multi-level governance in Part IV. The design and layout of the book has been reconsidered to make this edition as user-friendly as possible. Throughout we have tried to ensure that the illustrative material effectively complements the text. We have kept some of the tried and tested features, such as the definition boxes and other illustrative boxed material, although here have tried to make the boxes shorter and crisper. We have added 'comparative' boxes to illuminate our analysis of British politics by setting it in an international context. We have added more graphs and charts and tried to simplify the presentation of tables. However, to keep the overall length and cost of the book in reasonable proportions, and to avoid undue interference with the flow of the text, we decided to transfer some very useful features included in the old third edition to the new companion website.

New to this edition is a companion www site which can be found at <http://www.palgrave.com/ politics/coxall $>$ and performs a number of functions. One is obviously to provide regular updates on all the topics covered in the book as a result of on-going political events and developments, together with the latest scholarly analysis. We have also transferred to the website some of the features incorporated in previous editions, including additional teaching material, revision summaries, questions and assignments, which we have expanded and plan to continue to develop in future.

Bill Coxall, who wrote the first three editions of Contemporary British Politics with Lynton Robins, died in March 1999 shortly after publication of the third edition. This edition is dedicated to Bill, without whom it would not exist, and from whom it has inherited many of its most learned and fluent passages. He has been sadly missed in the preparation of this edition, for which the extensive new material has been written by Lynton Robins with Robert Leach, who has also taken over Bill Coxall's previous coordinating role. 


\section{Acknowledgements}

The authors and publishers are grateful to the following for permission to use copyright material: Steven Carroll for illustration in Table 3.1; PA photos for photographs in In Focus 1.1, 4.1, 6.1, 7.1, 9.1, 10.1, 12.3, 14.1, 15.1, 17.1, 18.1, 19.1, 21.1, 24.1, 26.1 ; COI for photograph in In Focus 12.1; Imagemakers London Ltd for photograph in In Focus 12.2; Steve Bell for cartoon in In Focus 22.1. Every effort has been made to trace all copyright holders of third party materials included in this work but if any have been inadvertently overlooked the publishers will be pleased to make the necessary arrangements at the first opportunity.

Robert Leach would like to thank his wife, Judith, for her understanding and forbearance throughout the preparation of this edition. Lynton Robins is grateful to his wife, Vivien, for her support. He would also like to thank his son Matthew, a Politics postgraduate, for his assistance in the library and for drafting possibilities for the final chapters. 


\section{List of abbreviations}

\begin{tabular}{|c|c|c|c|}
\hline ACEA & $\begin{array}{l}\text { Association of European Automobile } \\
\text { Companies }\end{array}$ & DHSS & $\begin{array}{l}\text { Department of Health and Social } \\
\text { Security }\end{array}$ \\
\hline $\mathrm{ACPO}$ & Association of Chief Police Officers & DID & Department of International \\
\hline AI & Amnesty International & & Development \\
\hline ALF & Animal Liberation Front & DMU & directly managed unit \\
\hline $\mathrm{AM}$ & additional member system & DOE & Department of the Environment \\
\hline APNI & Alliance Party of Northern Ireland & & (now part of DEFRA) \\
\hline ASH & Action on Smoking and Health & DSC & departmental select committee \\
\hline AV & alternative vote & DTI & Department of Trade and Industry \\
\hline \multirow[t]{2}{*}{ AWM } & Advantage West Midlands (develop- & DUP & Democratic Unionist Party \\
\hline & ment agency) & EAPC & Euro-Atlantic Partnership Council \\
\hline $\mathrm{BBC}$ & British Broadcasting Corporation & & (replaced by NATO-RC) \\
\hline \multirow[t]{2}{*}{ BEUC } & European Bureau of Consumers' & ECAS & European Citizen Action Service \\
\hline & Associations & ECHR & European Court of Human Rights \\
\hline BMA & British Medical Association & ECSC & European Coal and Steel \\
\hline $\mathrm{BMD}$ & ballistic missile defence shield & & Community \\
\hline BNP & British National Party & EDM & Early Day Motion \\
\hline BPPS & British Political Participation Survey & EEA & European Economic Area \\
\hline BSA & British Social Attitudes & EEB & European Environmental Bureau \\
\hline \multirow[t]{2}{*}{ BSE } & spongiform encephalitis & EEC & European Economic Community \\
\hline & ('mac & EEDA & East of England Development \\
\hline BUF & British Union of Fascists & & Agency \\
\hline CAP & Common Agricultural Policy & EFTA & European Free Trade Association \\
\hline CBI & Confederation of British Industry & EGO & extra-governmental organisation \\
\hline СCT & compulsory competitive tendering & EMDA & East Midlands Development Agency \\
\hline \multirow[t]{2}{*}{ CEFIC } & European Chemistry Industry & EMS & European Monetary System \\
\hline & Council & EMU & economic and monetary union \\
\hline \multirow[t]{2}{*}{ CEMR } & Council of European Municipalities & $\mathrm{EP}$ & European Parliament \\
\hline & and Regions & ERM & Exchange Rate Mechanism of the \\
\hline CLEAR & Campaign for Lead-Free Air & & EMS \\
\hline CLP & Constituency Labour Party & ESC & Economic and Social Co \\
\hline CND & Campaign for Nuclear Disarmament & ETUC & European Trade Union \\
\hline \multirow[t]{2}{*}{ COPA } & Committee of Professional Agricul- & & Confederation \\
\hline & & EU & European Union \\
\hline COREPER & $\begin{array}{l}\text { Committee of Permanent } \\
\text { Representatives (EU) }\end{array}$ & EUROBIT & $\begin{array}{l}\text { European Association of Manufactur- } \\
\text { ers of Business Machines and }\end{array}$ \\
\hline CPAG & Child Poverty Action Group & & Information Technology \\
\hline CPGB & Communist Party of Great Britain & $\mathrm{FCO}$ & Foreign and Commonwealth Office \\
\hline \multirow[t]{2}{*}{ CPRE } & Council for the Protection of Rural & FPTP & first-past-the post \\
\hline & England & FSA & Financial Services Authority \\
\hline & Commission for Racial Equality & GATT & General Agreement on Tariffs and \\
\hline \multirow[t]{2}{*}{ DEFRA } & Department of the Environment, & & Trade \\
\hline & Food and Rural Affairs & GCHQ & Government Communications \\
\hline DHA & District Health Authority & & Headquarters \\
\hline
\end{tabular}




\begin{tabular}{|c|c|c|c|}
\hline GDP & Gross Domestic Product & Ofgem & Office of Gas and Electricity \\
\hline GLA & Greater London Authority & & Markets \\
\hline GNP & Gross National Product & Ofsted & Office for Standards in Education \\
\hline GOR & government offices for the regions & OFT & Office of Fair Trading \\
\hline HAT & Housing Action Trust & Oftel & Office of Telecommunications \\
\hline IMF & International Monetary Fund & Ofwat & Office of Water Services \\
\hline \multirow[t]{2}{*}{ IMRO } & Investment Management Regulatory & OMOV & one man (person) one vote \\
\hline & Organisation & ONE & One North East (development \\
\hline INLA & Irish National Liberation Army & & agency) \\
\hline IPPR & $\begin{array}{l}\text { Institute for Public Policy } \\
\text { Research }\end{array}$ & OPEC & $\begin{array}{l}\text { Organisation of Petroleum } \\
\text { Exporting Countries }\end{array}$ \\
\hline IRA & Irish Republican Army & ORR & Office of the Rail Regulator \\
\hline \multirow[t]{2}{*}{ IRC } & Industrial Reorganisation & PAC & Public Accounts Committee \\
\hline & Corporation & $\mathrm{PC}$ & Plaid Cymru \\
\hline ITA & Independent Television Authority & PESC & Public Expenditure Survey \\
\hline LA & local authority & & Committee \\
\hline LSE & London School of Economics & PFI & private finance initiative \\
\hline LMS & local management of schools & PfP & Partnership for Peace (for former \\
\hline MAD & mutually assured destruction & & Warsaw Pact members, now replaced \\
\hline \multirow[t]{3}{*}{ MAFF } & Ministry of Agriculture, Fisheries & & by EAPC) \\
\hline & and Food (now subsumed into & PLP & Parliamentary Labour Party \\
\hline & DEFRA) & PM & Prime Minister \\
\hline \multirow[t]{2}{*}{ MEP } & member of the European & PMQT & Prime Minister's Question Time \\
\hline & Parliament & PPP & public-private partnerships \\
\hline \multirow[t]{2}{*}{ MINIS } & Management Information System for & PPS & Parliamentary Private Secretary \\
\hline & Ministers & $\mathrm{PR}$ & proportional representation \\
\hline MLR & Minimum Lending Rate & PSAs & public service agreements \\
\hline MoD & Ministry of Defence & PSBR & Public Sector Borrowing \\
\hline MP & Member of Parliament & & Requirement \\
\hline MSP & Member of the Scottish Parliament & PUP & Progressive Unionist Party \\
\hline MWA & Member of the Welsh Assembly & QAA & Qualifications and Assessments \\
\hline \multirow[t]{2}{*}{ NATO } & North Atlantic Treaty & & Authority \\
\hline & Organisation & QMV & qualified majority voting \\
\hline NATO-RC & NATO-Russia Council & qualgo & quasi-autonomous local \\
\hline NDO & non-departmental body & & government organisation \\
\hline NDPB & non-departmental public body & quango & quasi-autonomous non-governmental \\
\hline NEB & National Enterprise Board & & organisation \\
\hline \multirow[t]{2}{*}{ NEC } & National Executive Committee & RDA & regional development agency \\
\hline & (of the Labour Party) & RSPB & Royal Society for the Protection of \\
\hline \multirow[t]{2}{*}{ NEDC } & National Economic Development & & Birds \\
\hline & Council (now defunct) & RSPCA & Royal Society for the Prevention of \\
\hline NF & National Front & & Cruelty to Animals \\
\hline NFU & National Farmers' Union & SCS & Senior Civil Service \\
\hline NHS & National Health Service & SDLP & Social Democratic and Labour Party \\
\hline NIA & Northern Ireland Assembly & SDP & Social Democratic Party (now \\
\hline NNDR & national non-domestic rates & & subsumed into Liberal Democratic \\
\hline NWDA & Northwest Development Agency & & Party) \\
\hline \multirow[t]{2}{*}{ OECD } & Organisation for Economic & SDR & strategic defence review \\
\hline & Cooperation and Development & SEA & Single European Act \\
\hline
\end{tabular}




\begin{tabular}{|c|c|c|c|}
\hline SEEDA & $\begin{array}{l}\text { South East England Development } \\
\text { Agency }\end{array}$ & $\begin{array}{l}\text { UKIP } \\
\text { UKUP }\end{array}$ & $\begin{array}{l}\text { UK Independence Party } \\
\text { United Kingdom Unionist Party }\end{array}$ \\
\hline SF & Sinn Fein & UN & United Nations \\
\hline SNP & Scottish National Party & UNICE & Union of Industrial and \\
\hline SOLACE & $\begin{array}{l}\text { Society of Local Authority Chief } \\
\text { Executives }\end{array}$ & & $\begin{array}{l}\text { Employers' Confederations of } \\
\text { Europe }\end{array}$ \\
\hline SSP & Scottish Socialist Party & USA & United States of America \\
\hline STV & single transferable vote & UUP & Ulster Unionist Party \\
\hline SWERDA & $\begin{array}{l}\text { South West of England Regional } \\
\text { Development Agency }\end{array}$ & $\begin{array}{l}\text { UVF } \\
\text { VAT }\end{array}$ & $\begin{array}{l}\text { Ulster Volunteer Force } \\
\text { value added tax }\end{array}$ \\
\hline SWP & Socialist Workers' Party & vCJD & variant Creutzfeld-Jacob disease \\
\hline TGWU & $\begin{array}{l}\text { Transport and General Workers } \\
\text { Union }\end{array}$ & & $\begin{array}{l}\text { (the human variant of 'mad cow' } \\
\text { disease }\end{array}$ \\
\hline TUC & Trades Union Congress & WA & Welsh Assembly \\
\hline UDA & Ulster Defence Association & WRP & Workers' Revolutionary Party \\
\hline UDC & Urban Development Corporation & WTO & World Trade Organisation \\
\hline UDP & Ulster Democratic Party & YF & Yorkshire Forward (development \\
\hline UK & United Kingdom & & agency) \\
\hline
\end{tabular}

